\title{
The Green Hotel Knowledge Towards Consumer Behavior Intention:
}

\author{
Empirical Model Testing
}

\author{
Robert Kristaung, Luki Adiati Pratomo* \\ Faculty of Business and Economics \\ Universitas Trisakti \\ Jakarta, Indonesia \\ *luki.trisakti@gmail.com
}

\begin{abstract}
The results of the study empirically prove that attitudes, subjective norms, and perceived behavioral control have a significant effect on hotel customer intentions. The study aimed to find the most influential role of the green hotel knowledge, among control, mediating, or moderating variable toward consumer behavioral intention. The finding of this study confirms that the most substantial role of green hotel knowledge as a mediator between attitude, the subjective norm as well as perceived behavioral control, and marketing performance in terms of customer intentions. Managerial implications for emerging market countries such as Indonesia, lack of green hotel knowledge and requires market education from three actors, namely academics, practitioners, and regulators.
\end{abstract}

Keywords-attitude, subjective norm, perceived behavioral control, green hotel knowledge, behavior intention

\section{INTRODUCTION}

The terminology for hotels that considered environmentally friendly is quite diverse. Some of these terms include eco-green [1], or sustainable hotels [2]. These hotels are oriented towards nature and focus on being environmentally friendly, using energy, water, and materials that are not harmful to the environment [3].

In Indonesia, the hotel industry is less concerned with implementing environmentally-friendly measures when compared to other ASEAN countries such as Malaysia, Singapore, and Thailand [1]. However, guidelines called the ASEAN Green Hotel Standard had been issued for proper economic cooperation. Hotel care currently advised to undergo eco-certification and environmental management standards based on ISO 14001 [4-6].

The alignments of hotel management in environmental preservation activities are triggered by economic and ethical considerations derived from personal values and beliefs [7]. The best predictor of marketing these proactive measures found on some of the contextual variables are organized, through foreign tourists (Western Europe and the USA), affiliated extremists international hotel chain, demographic factors such as age and gender as well as education [5,7-10]

Various studies previously conducted on green hotels $[2,3,11]$. However, this study aims to determine the gaps in consumer behavior in maintaining the growing perspective of a friendly environment. Conversely, it aims to empirically examine the relationship between returning consumer environmental behavior and consumer propensity to stay at a hotel and the role of green hotel knowledge as a control, mediating, and moderating variable.

\section{LITERATURE REVIEW}

Green marketing refers to all the efforts made by companies to design, promote, establish, and distribute prices with the least possible impact on the environment [12]. In promoting green marketing, marketers have to provide information on the effects of products and services in preserving the environment to their target consumer, which is expected to influence behavioral decisions.

Consumers obtain environmentally friendly products through advertisements that are claimed to be credible, with adequate knowledge of the importance of nature conservation responsive to environmentally friendly products and promotions $[13,14]$. These products are increasingly playing key roles in the consumer buying and repurchase decision process [15]. In relation to the attitude which is liked or disliked by people, it is a comprehensive evaluation of specific behaviors.

The attitude of consumers to return to an environmentally friendly hotel usually has positive feelings [16]. Previous studies have indicated that their attitudes positively influences their decision, with the desire to spend more time $[8,13,17]$. Attitudes affect the return of tourists in the future $[4,10,15,18]$. Therefore, it has a significant effect on the intention of hotel customers.

Furthermore, subjective norms associated with awareness of social pressures, influence attitudes of one's behavioral 
intentions [19]. Empirically, there is a relationship between subjective norms and hotel customer attitudes and plays an essential role in a customer's decision $[13,20]$ and eventually revisit it subsequently $[21,22]$. Therefore, subjective norms have a significant effect on the intention of customers.

Perceived behavioral control also gives an idea of one's ability to control the various factors that tend to influence their behavior [23]. Classically, it has been accepted that perceived behavioral control is one of the predictor variables of one's intentions [24]. The behavior of hotel customers towards green hotels is determined by their resources and the awareness to pay for a conventional hotel $[4,23]$.

These intentions are one of the strengths for the emergence of certain behaviors, which are interpreted as someone's willingness to stay back at a hotel [25]. This intention has the dimension of spreading positive or negative news, willingness or unwillingness to pay premium prices, and the plan to revisit or switch to other hotels/resorts. In brief, the intention to visit a hotel is a bond of positive communication attitude, and a willingness to pay more for a green hotel. Consumer attitudes toward environmentally friendly behavior are significant predictors of intentions to provide positive recommendations $[13,17,22]$.

This knowledge is related to understanding information on a hotel that supports the preservation and environmentally friendly practices that run in the hospitality business operations $[4,22]$. Customer understanding of the green hotel tends to have an impact on the desire to stay and the willingness to revisit. When visitors return to a particular hotel, it means that they obtained a positive experience during their last stay or paid attention to the preservation of the environment (nature). The overall image affects customer intentions to provide positive recommendations and willingness to return [16,22]. In other words, green hotel knowledge mediates and moderates the relationship between consumer behavior aware of environmental sustainability.

\section{METHODOLOGY}

Structural Equation Modelling (SEM) was employed to test the hypotheses of this study [26]. A survey with purposive sampling was used to select the respondents consisting of 143 guests of 3 (three) and 4 (four) stars environmentally friendly and conventional hotels in Jakarta.

The demographic sample consists of 44 women (33.6\%) and 95 men $(66.4 \%)$. Ninety-seven people $(67.9 \%)$ within the age range of 26 to 35 years. The rest were less than 25 years, with 46 people above 35 years $(32.1 \%)$. The design of the hotel visited or stayed remains quite balanced between conventional design with 72 (50.3) and eco-friendly of 71 (49.7\%).

The results of testing the research instruments for the five variables are attitude, subjective norm, perceived behavioral control, green hotel knowledge, and behavioral intention. Each variable measured by three indicators sourced from previous studies $[1,3,27]$. All the measurement tools are valid because it obtained a correlation value of more than 0.50 and reliable based on Cronbach's reliability value above 0.60 . The theoretical measurement model obtained only for constructs of green hotel knowledge in terms of reliability is less than 0.70 as required, while the extracted variance was 0.50 .

Goodness-of-fit results in the category of absolute fit measures with 80 degrees of freedom, minimum Chi-Square function of $103.36(\mathrm{P}=0.041), 104.19$ normal Theory Weight $(\mathrm{P}=0.036)$, and 0.046 Root Mean Square Error Approximation (RMSEA). This meets the required criteria of Incremental Fit Measures and the required criteria by looking at the Normed Fit Index $(\mathrm{NFI})=0.87$, Non-Normed Fit Index $(\mathrm{NNFI})=0.96$; Comparative Fit Index $(\mathrm{CFI})=0.97$, Incremental Fit Index $(\mathrm{IFI})=0.97$, Goodness of Fit Index $(\mathrm{GFI})=0.91$, and Adjusted Goodness of Fit Index $($ AGFI $)=0.87$. Similarly, Parsimonious Fit Measures met the requirements with the Parsimony value Normed Fit Index (PNFI) of 0.66 and 0.61 Parsimony Goodness of Fit Index (PGFI). Therefore, the three criteria of the model tested to fulfill the requirements as a model with good goodness-of-fit criteria - the four models tested with assistive devices sta LISREL Tistik 8.8.

\section{RESULTS AND DISCUSSION}

The results of testing the first model of attitudes, subjective norms, and perceived behavioral control have a significant effect on the intention of hotel customers to stay at a green hotel show that all three variables have a significant effect. This is determined based on the t-count higher than $t$ table (1.96) at the level of confidence p-value $<0.05$. The most crucial variable influence in this first model is the perceived behavioral control, and the weakest is the attitude towards the intention of hotel customers to stay at a green hotel. It means when the customer believes that they have the resources to take care of the environment, the strongest their intention to revisit the green hotel.

The results of testing the second model on green hotel knowledge as a control variable influenced customer intentions, which is a perceived behavioral control variable with a significant effect. This is due to the value of the t-count perceived behavioral control, which is higher than t-table (1.96) at the level of confidence $p$ - value $<0.05$. Meanwhile, the other three variables are smaller than t-table (1.96) at the level of confidence p-value $<0.05$. Therefore, attitudes, subjective norms, and green hotel knowledge do not have a significant influence on visitors' behavior intention to stay.

The results of testing the mediation role of green hotel knowledge between attitudes, subjective norms and perceived behavioral control of behavioral intention are determined by the indirect effect of these three variables on behavioral intention, with all consisting of t-count higher than t-table (1.96) at the level of confidence p-value <0.05. Therefore, green hotel knowledge has a significant mediating role, with an indirect attitude towards behavioral. This result portrays how necessary green hotel knowledge toward customers' intention to stay again in the green hotel. Customers who have a good 
understanding of environment friendly will have a strong intention to revisit the green hotel.

The difference in the chi-square value obtained by 0.47916 was 2 of $0.479158<3.84146$, with the calculated chi-square value higher than the (X2) table. Therefore, the structural equation model of the constrained parameter is not constrained; it means that there are differences between the moderating variables of high and low green hotel knowledge.

The moderation function, which plays a role in these three variables is a high group of green hotel knowledge, because it has t-count higher than t-table (1.96), at a level of confidence $\mathrm{p}$-value <0.05. However, for groups with low green hotel knowledge, only subjective norms have a significant moderation function.

It means that consumers 'desire to return to using green hotel services is influenced by their attitudes towards environmental issues, subjective norms, and perceived behavioral control, which has the most potent influence. Therefore, the stronger a person's on possessing adequate resources to help protect the environment, the higher their desire to return to using a green hotel.

\section{CONCLUSION}

Attitudes, subjective norms, and perceived behavioral control have a significant effect on the intention of hotel customers. Also, the knowledge acts as a control variable influences customer's intention, which is the only the perceived behavioral control variable with a significant effect.

The mediating role of green hotel knowledge between attitudes, subjective norms, and perceived behavioral control on behavioral intention plays a significant role. Therefore, the stronger the indirect attitude towards behavioral intention, the smaller the subjective norm. The moderation function that plays a role in all three variables is the group with high green hotel knowledge. In contrast, those with low knowledge are the subjective norm with a significant moderation function.

\section{REFERENCES}

[1] N.M. Suki and A.S.A. Salleh, "Mediating effect of Halal image on Muslim consumers' intention to patronize retail stores: Some insights from Malaysia," J Islam Mark, Vol. 9, No. 2, pp. 338-55, 2018.

[2] E. Cavagnaro E, Influencing Guest Behaviour Towards Sustainable Hotel Choice By Distribution Channels Niels van Felius, pp. 502-16, 2016.

[3] A. Chen and N. Peng, "Green hotel knowledge and tourists' staying behavior," Ann Tour Res., Vol. 39, No. 4, pp. 2211-6, 2012.

[4] T.A. Aulinadri and R. Angraeny, "The Implementation of Green Hotel Management Standard in Majapahit Hotel Indonesia," Int J Organ Innov., Vol. 9, No. 3, pp. 45-62, 2017.

[5] C. Teng, A. Cheng and C. Lu, Drivers of consumers behavioral intention toward green hotels, 2017.

[6] C.G. Baicu, I.M. Oehler-Sincai, O. State and D. Popescu, "Bioeconomy and social responsibility in the sustainable hotel industry," Amfiteatru Econ. Vol. 21, No. 52, pp. 485-99, 2019.
[7] J. Wang, S. Wang, Y. Wang, J. Li and D. Zhao, "Extending the theory of planned behavior to understand consumers' intentions to visit green hotels in the Chinese context," Contemp Hosp Manag., Vol. 30, No. 8, pp. 2810-925, 2018.

[8] F. Apaydin and M. Szczepaniak, "Analyzing the Profile and Purchase Intentions of Green Consumers in Poland," Ekonomika, Vol. 96, No. 1, pp. 93, 2017.

[9] G. Karavasilis, D. Nerantzaki, P. Pantelidis, D. Paschaloudis and V. Vrana, "What Generation Y in Greece thinks about Green Hotels George. WJEMSD 11,4 268 Receiv 17 Febr 2015 Revis 22 March 2015 Accept 6 April 2015 What Gener Y Greece thinks about Green Hotel Georg Karavasilis, Dafni-Maria Nerantzaki, Panagiotis Pantelidis, Dimitrios Paschaloudis Vasiliki Vrana Depart [Internet]. 2015;11(4):268-80. Available from: http://dx.doi.org/10.1\%5Cn108/WJEMSD-1\%5Cn1-2013-005\%5Cn

[10] M.S. Rosenbaum and I.A. Wong, "Green marketing programs as strategic initiatives in hospitality," J Serv Mark. Vol. 29, No. 2, pp. 8192, 2015.

[11] N.M. Suki and A.S.A. Salleh, "Mediating effect of Halal image on Muslim consumers' intention to patronize retail stores: some insights from Malaysia,” J Islam Mark. Vol. 4, No. 1, 2017.

[12] K. Peattie and A. Crane, "Green marketing: Legend, myth, farce or prophesy?," Qual Mark Res An Int J. Vol. 8, No. 4, pp. 357-70, 2005.

[13] J. Wang, S. Wang, Y. Wang, J. Li and D. Zhao, "Extending the theory of planned behavior to understand consumers' intentions to visit green hotels in the Chinese context," Int J Contemp Hosp Manag, Vol. 30, No. 8, pp. 2810-25, 2018.

[14] M.J. Polonsky, "Transformative green marketing: Impediments and opportunities," J Bus Res., Vol. 64, No. 12, pp. 1311-9, 2011.

[15] J.P. Govender and T.L. Govender, "The influence of green marketing on consumer purchase behavior," Environ Econ. Vol. 7, No. 2, pp. 77-85, 2016.

[16] C.C. Teng, A.C.C. Lu and T.T. Huang, "Drivers of consumers' behavioral intention toward green hotels," Int J Contemp Hosp Manag., Vol. 30, No. 2, pp. 1134-51, 2018.

[17] Z. Mohaidin, K.T. Wei and M.A. Murshid, "Factors Influencing the Tourists' Intention to Select Sustainable Tourism Destination: A Case Study of Penang, Malaysia," International Journal of Tourism Cities, pp. $1-5,2010$.

[18] C. Xie, R.P. Bagozzi and K. Grønhaug, "The role of moral emotions and individual differences in consumer responses to corporate green and non-green actions," J Acad Mark Sci. Vol. 43, No. 3, pp. 333-56, 2015.

[19] S. Shokohyar, R. Tavallaee and K. Karamatnia, "Identifying Effective Indicators in the Assessment of Organizational Readiness for Accepting Social CRM," Int J Manag Account Econ. Vol. 3, No. 2, pp. 85-104, 2016.

[20] C.M.F. Tang and D. Lam, "The role of extraversion and agreeableness traits on Gen Y's attitudes and willingness to pay for green hotels," Int J Contemp Hosp Manag., Vol. 29, No. 1, pp. 607-23, 2017.

[21] Y-H. Wang, S-T Chen and N-N Chen, "An Empirical Study of the Effect of Green Marketing on Purchase Intention - Evidence from Green Restaurant," Adv Manag Appl Econ., Vol. 6, No. 4, pp. 1-14, 2016.

[22] Y.L. Gao and A.S. Mattila, "The Impact of Option Popularity, Socia Inclusion/Exclusion, and Self-affirmation on Consumers' Propensity to Choose Green Hotels," J Bus Ethics, Vol. 136, No. 3, pp. 575-85, 2016.

[23] N.L. Yong, S.K. Ariffin, G.Y. Nee and N.A. Wahid, “A Study of Factors influencing Consumer's Purchase Intention toward Green Vehicles: Evidence from Malaysia," Glob Bus Manag Res., Vol. 9, No. 4, pp. 281-97, 2017.

[24] A. Sukhu and R. Scharff, "Will "doing right" Lead to "doing well"? An Examination of Green Behavior," J Consum Mark. Vol. 35, No. 2, pp. 169-82, 2018.

[25] K.A. Sun and D.Y. Kim, "Does customer satisfaction increase firm performance? An application of American Customer Satisfaction Index (ACSI),” Int J Hosp Manag., Vol. 35, pp. 68-77, 2013.

[26] [26] K.G. Jöreskog, U.H. Olsson and F.Y. Wallentin, Multivariate Analysis with LISREL. Basel, Switzerland: Springer International Publishing AG; 2016. 1-561 p.

[27] [27] Niels van Felius, Marit de Vries and E. Cavagnaro, Influencing Guest Behaviour Towards Sustainable Hotel Choice By Distribution Channels Niels van Felius, pp. 502-16, 2016. 